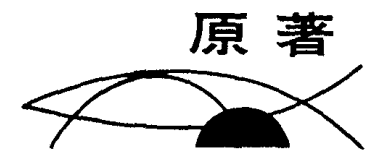

\title{
酵素洗剤中プロテアーゼ活性の保存安定性および 洗浄時温度と洗浄力の関係に関する研究
}

\author{
伏見了* 野口悟司* 船越文男* \\ 高階雅紀* 中田精三* 田野保雄*
}

\begin{abstract}
Studies on Stability of Protease during Storage and on the Relationship between Temperatures and Washing Ability of the Detergents for Operation Apparatus
\end{abstract}

Ryo Fushimi*, Satoshi Noguchi*, Fumio Funakoshi*, Masaki Takashina*, Seizou Nakata* and Yasuo Tano*

* Surgical Center, Osaka University Hospital

\begin{abstract}
Detergents contained enzymes that claim stronger washing ability and less damages are used widely for washing out blood or minute tissues adhered to various operation apparatus. It is known that enzyme protein shows maximum activity at $40^{\circ} \mathrm{C}$ and is more stable when stored at the lower temperature. However, detergents contained enzymes are stored at room temperature in the most of operation theaters, and furthermore they are transported from manufacturers to any of distribution route in nonrefrigerated condition. When we measured Protease activities at $4{ }^{\circ} \mathrm{C}$ and $40^{\circ} \mathrm{C}$ during 161 days storage period, the activity at $4{ }^{\circ} \mathrm{C}$ was stable but at $40^{\circ} \mathrm{C}$ decreased $38.0 \%$ in average. In comparison of Protease activities at $20^{\circ} \mathrm{C}$ and $40^{\circ} \mathrm{C}$, the latter showed twice higher activity. When we studied the correlation between temperatures and the washing ability of detergents contained enzymes using Adenosine triphosphate as the marker, the washing ability at $40^{\circ} \mathrm{C}$ was stronger than that at $20^{\circ} \mathrm{C}$.

\section{1. 目的}

手術に使用した各種器械には血液や微細組織 片なら゙が付着している ${ }^{1,2)}$. これら器械の洗浄は 感染予防や円滑な作動の維持などにおいて非常 に重要であり, 洗浄効果を向上させる目的で超 音波洗浄などの前に器械をプロテアーゼなよ゙

を含む酵素洗剤に浸漬する方法が広く実施され ている32. 酵素は触媒機能を有する蛋白質であ

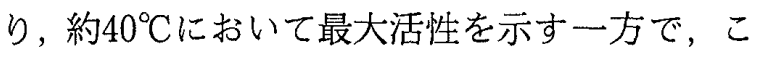
の温度では時間とともに失活することも知られ ている.ほとんどの手術部や材料部では酵素洗 剤を室温にて保存し, 浸漬洗浄時も洗剤液の加 温などをしていない，さらに，製造元からの流 通経路においても酵素洗荗を保冷するなどの処 置がなされていない。


医器学 Vol. 70, No.12 (2000) ( 7 )

われわれは, 製造直後の酵素洗剤（4種類） を $4{ }^{\circ} \mathrm{C}$ 抢よび $40^{\circ} \mathrm{C} に 161$ 日間保存し，その期間 中のプロテアーゼ活性を測定した．また，プロ テアーゼ活性測定時の反応温度を $20^{\circ} \mathrm{C}$ か $440^{\circ} \mathrm{C}$ まで変化させて活性值を比較した，さらに，ア デノシン三リン酸を指標として浸漬洗浄時の温 度 $\left(20^{\circ} \mathrm{C}\right.$ よび $\left.40^{\circ} \mathrm{C}\right)$ と洗浄力の関係について 実験を行った。

\section{2. 材料および方法}

\section{1）実験に用いた酵素洗剂}

アルベスト BF (発売元：アルボース）, エ ンドフレッシュ A (発売元 : オリンパス販売), ステリザイム (発売元 : 丸石製薬)，メディポー ル EX-1 (発売元 : 乾商事) 以上 4 種類，いず れあ発売元のご好意により製造直後の洗郕を入 手し実験に用いた。

\section{2）プロテアーゼ活性測定法 ${ }^{4-6)}$}

精製水にて $1.0 \%$ に希积した各酵素洗剂を 試料として, $40^{\circ} \mathrm{C} に て 2.0 \%$ ミルクガイン （pH 7.0）を基質とし，生成したアミノ酸をフェ ノール試薬で定量してプロテアーゼ活性を求め た. 1 分間に $1 \mu \mathrm{g}$ チロシンに相当する呈色をプ ロテアーゼ活性 $1.0 \mathrm{U} / \mathrm{L}$ とした。

4 種類の製造直後の酵素洗剤原液を $4^{\circ} \mathrm{C}$ お び40ㄷにて161日間保存し，その期間中におい て 1 日目，30日目，78日目，104日目，133日目 および161日目に各社酵素洗剤を精製水にて1.0 \%に希釈したものを試料としてプロテアーゼ活 性を測定した。

また， $1.0 \%$ アルベスト $\mathrm{BF}$ を試料とし，活 性測定時の反応温度を $20^{\circ} \mathrm{C}$ から $40^{\circ} \mathrm{C}$ まで $5^{\circ} \mathrm{C}$ 間
隔に変化させてプロテアーゼ活性を測定した。

3）アデノシンシリン酸（以下，ATP）濃度 測定法 $2,7 \sim 8)$

ATP がルシフェリンと酸素の存在下でルシ フェラーゼの触媒により発光する原理に基づく 方法にて測定した。試薬としてルシフェライト， 測定装置にルミテスタ K-210を使用した（試 薬，装置とすに日水製薬).

\section{4）洗浄時の温度と洗浄力確認実験}

30本のハサミを用意し，6本を 1 セットとし た. $1.0 \%$ \%アルベスト $\mathrm{BF}$, エンドフレッシュ. $\mathrm{A}$ ，ステリザイムおよびメディポール EX-1を $20^{\circ} \mathrm{C}, 40^{\circ} \mathrm{C}$ に保温した. 水道水を同様に保温し たものを対照とした，すべてのハサミに血液 $1.0 \mathrm{ml}$ を塗布し室温にて 2 時間放置した。八少 ミの一方の刃部分で ATP 濃度を測定した後に 各 3 本を $20^{\circ} \mathrm{C}, 40^{\circ} \mathrm{C}$ の洗剂液および対照である 水道水に 5 分間浸漬した. 水道水にて 10 分間す すいだ後に室温にて乾燥させ, 他方の刃部分の ATP 濃度を測定した。

\section{3. 成}

4 種類の製造直後の酵素洗剤を $4^{\circ} \mathrm{C}$ および 40 ${ }^{\circ} \mathrm{C} に 161$ 日間保存し，それぞれにおいてプロテ アーゼ活性を測定した成績を表 1 に示す，4 種 類ともに $4^{\circ} \mathrm{C}$ 保存では安定した活性を示したが, $40^{\circ} \mathrm{C}$ 保存ではエンドフレッシュ $\mathrm{A}$ が 30 日目に 77,000, 133 日目では 41,000 U/L, 同様にアル ベスト BF が $66,000,47,000 \mathrm{U} / \mathrm{L}$,メディポー ル EX-1 が 30,000, 17,000 U/L と活性が大きく 低下した。しかし，ステリザイムでは 41,000, 37,000 U/L と活性がかなり保たれていた。

表 $14^{\circ} \mathrm{C}$ および $40^{\circ} \mathrm{C}$ 保存における酵素含有洗剂中のプロテアーゼ活性值の変化

（洗剂を原液で保存し、測定時に精製水にて $1.0 \%$ に希䣋）

\begin{tabular}{|c|c|c|c|c|c|c|c|}
\hline \multirow{3}{*}{ 醇素洗浏名 } & \multirow{3}{*}{$\begin{array}{c}\text { 保存温度 } \\
\left({ }^{\circ} \mathrm{C}\right)\end{array}$} & \multicolumn{6}{|c|}{ プロテアーゼ活性值 (U/L) } \\
\hline & & \multicolumn{6}{|c|}{ 保存日数 } \\
\hline & & 1日目 & 30日目 & 78日目 & 104 日目 & 133日目 & 161 日目 \\
\hline エンドフレッシュ A & \multirow{4}{*}{4} & 78000 & 80000 & 76000 & 75000 & 76000 & 75000 \\
\hline アルベスト BF & & 66000 & 67000 & 63000 & 60000 & 62000 & 61000 \\
\hline メディポール EX-1 & & 33000 & 35000 & 31000 & 30000 & 29000 & 28000 \\
\hline ステリザイム & & 44000 & 47000 & 46000 & 43000 & 43000 & 41000 \\
\hline エンドフレッシュ A & \multirow{4}{*}{40} & & 77000 & 55000 & 45000 & 41000 & 35000 \\
\hline アルベスト BF & & & 66000 & 49000 & 51000 & 47000 & 46000 \\
\hline メディポール $E X-1$ & & & 30000 & 24000 & 20000 & 17000 & 17000 \\
\hline ステリザイム & & & 41000 & 40000 & 36000 & 37000 & 36000 \\
\hline
\end{tabular}


( 8 ) 医器学 Vol. 70, No.12 (2000)

なお，プロテアーゼ活性測定における分析精 度は $\mathrm{n}=7$, mean $=21,429 \mathrm{U} / \mathrm{L}, \mathrm{SD}=1,134, \mathrm{C}$ $\mathrm{V}(\%)=5.3$ 执よび $\mathrm{n}=7$, mean $=70,714 \mathrm{U} / \mathrm{L}$, $\mathrm{SD}=2,430, \mathrm{CV}(\%)=3.4$ と良好であった。

精製水にて $1.0 \%$ に希釈したアルベスト $\mathrm{BF}$ を試料とし, 反応温度を $20^{\circ} \mathrm{C}$ か $40^{\circ} \mathrm{C}$ まて $5{ }^{\circ} \mathrm{C}$ 間隔に変化させてプロテアーゼ活性を測定し た成績を図 1 に示す。プロテアーゼ活性が40 ${ }^{\circ} \mathrm{C}$ で $62,700 \mathrm{U} / \mathrm{L}, 35^{\circ} \mathrm{C}$ で $48,100 \mathrm{U} / \mathrm{L}, 30^{\circ} \mathrm{C}$ で $39,000 \mathrm{U} / \mathrm{L}, 25^{\circ} \mathrm{C}$ で $30,500 \mathrm{U} / \mathrm{L}$, そして $20^{\circ} \mathrm{C}$ では $22,700 \mathrm{U} / \mathrm{L}$ を示した。

$20^{\circ} \mathrm{C}$ および $40^{\circ} \mathrm{C}$ に保温した 4 種類の $1.0 \%$ 酵 素洗剤液に血液を塗布した八サミを浸漬し，水 洗, 乾燥の後に付着している ATP 濃度を測定 した成績を表 2 に示す. 洗浄前には $1.09 \times 10^{-10}$ から $2.25 \times 10^{-8} \mathrm{~mol} / \mathrm{ml}$ の ATP がハサミ表 面に付着していたが $20^{\circ} \mathrm{C} ， 5$ 分間の浸漬洗浄に より $1.66 \times 10^{-13}$ から $2.88 \times 10^{-12} \mathrm{~mol} / \mathrm{ml}$ まで 減少した。さらに， $40^{\circ} \mathrm{C}$ の洗剂による洗浄では ATP が $2.02 \times 10^{-14}$ から $2.72 \times 10^{-13} \mathrm{~mol} / \mathrm{ml}$ ま で減少した。一方，対照である水道水では $40^{\circ} \mathrm{C}$ でも付着 ATP が $6.34 \times 10^{-13}$ から $2.03 \times 10^{-12}$ $\mathrm{mol} / \mathrm{ml}$ と $20^{\circ} \mathrm{C}$ とほぼ同様な成績であった。

\section{4. 考 察}

酵素洗剂は $\mathrm{pH}$ が中性域のため器械に対する 損傷が少なく, より効果的な器械洗浄方法の構 築を目指すわれわれにとって非常に有効な武器 である。しかし，酵素は蛋白質であるため水溶 液状態で，かつ高温環境下では失活しやすいこ とも良く知られている。

このようなことから，医薬および診断薬とし て使用されている酵素製剤は凍結乾燥され，し かも保冷状態で供給されて使用直前に溶解, 調 製することが基本仕様となっている.

ほぼ全ての医療器具洗浄用酵素洗剂は水溶液 の状態で商品として製造され，流通および保管 時においても保冷などの処置は取られていない， そこで, 製造直後の 4 種類の酵素洗剤原液を 4 ${ }^{\circ} \mathrm{C}$ おる゙ $40^{\circ} \mathrm{C} に 161$ 日間保存し，その期間中に おいてそのつど精製水にて $1.0 \%$ に希釈したも のを試料としてプロテアーゼ活性を測定した。

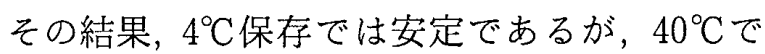

は 1 日目に比較して保存 161 日目では18.2から $55.1 \%$ （平均 38.0\%）活性が低下した（表 1 ）. ただし，ステリザイムは比較的安定であった。 この原因として酵素の由来の違いや酵素安定化 剤の工夫などが考えられる。

保存時には低温なほどプロテアーゼ活性は安 定なことが判明したが, 酵素の触媒活性は一般 的に $40^{\circ} \mathrm{C}$ 前後で最大を示す. $1.0 \%$ アルベスト $\mathrm{BF}$ を試料として $20 ， 25 ， 30 ， 35,40^{\circ} \mathrm{C}$ てプロ テアーゼ活性を測定した結果, $40^{\circ} \mathrm{C}$ のプテアー ゼ活性を $100 \%$ とすると $30^{\circ} \mathrm{C}$ では $62 \%, 20^{\circ} \mathrm{C}$ で は36\%の活性であった（図 1 ).つまり，分解 酵素としてのプロテアーゼの能力を引き出し， 効果的な洗浄を行うためには洗浄時に洗剤液を $40^{\circ} \mathrm{C}$ に加温することが重要である.

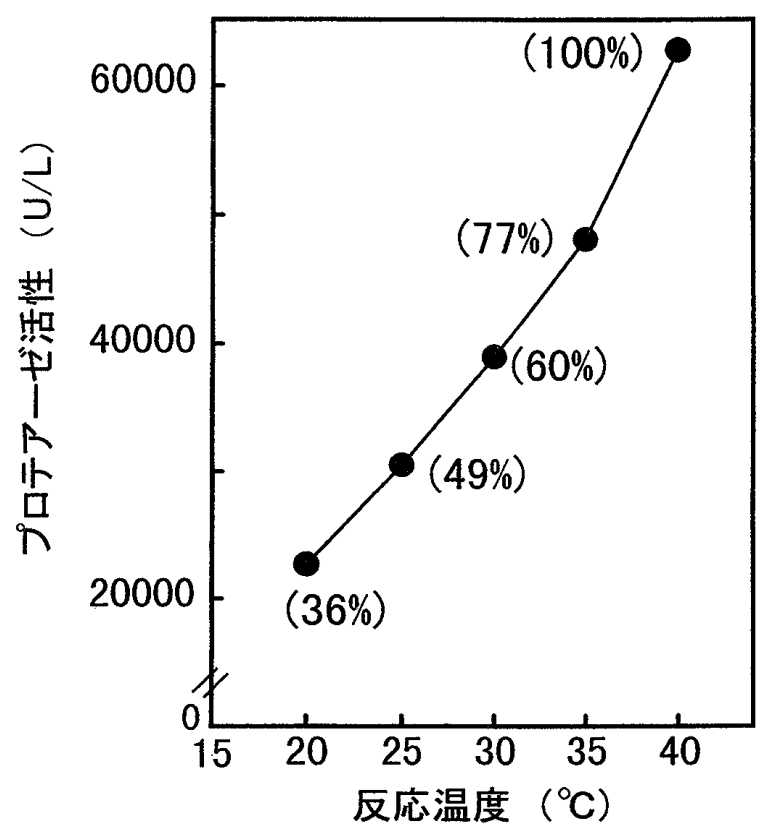

図 1 プロテアーゼ活性測定時の反応温度と 活性値の関係

このことを確認するため, 洗浄効果判定用污 染モデルとして血液を塗布した八サミを $20^{\circ} \mathrm{C} お$ よび $40^{\circ} \mathrm{C}$ の $1.0 \%$ 酵素洗剤液に浸漬して残存し ている血液由来 ATP 濃度を測定した（表 2 ）。 浸漬前に $10^{-9} \mathrm{~mol} / \mathrm{ml}$ オーダで付着していた $\mathrm{ATP}$ が $20^{\circ} \mathrm{C}, 5$ 分間の浸漬で $10^{-13} \mathrm{~mol} / \mathrm{ml}$ オー ダまで減少した。つまり, 付着 ATP 量が約 1 万分の 1 となった。そして $40^{\circ} \mathrm{C}, 5$ 分間の浸 漬では $10^{-14} \mathrm{~mol} / \mathrm{ml}$ オーダと約 10 万分の 1 と

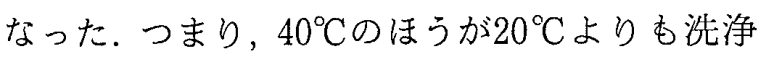
力が10倍向上したことを示している.さらに， 
表 2 の成績からは対照である水道水でも $20^{\circ} \mathrm{C}$, 5 分間の浸漬で付着 ATP 量が酵素洗剂と同様 に $10^{-13} \mathrm{~mol} / \mathrm{ml}$ オーダまで減少した.つまり， $20^{\circ} \mathrm{C}$ では水道水でも酵素洗剤でも洗浄力に変化

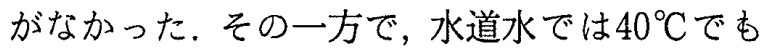
$20^{\circ} \mathrm{C}$ とぼ同様な洗浄効果しか得られなかっ た。

表 2 ATP 濃度を指標とした洗浄時温度と 洗浄力の関係

\begin{tabular}{|c|c|c|c|}
\hline \multirow{3}{*}{ 醇素洗鼡名 } & \multicolumn{3}{|c|}{$A T P \quad(\mathrm{~mol} / \mathrm{ml})$} \\
\hline & \multirow{2}{*}{$\begin{array}{c}\text { 洗 浄 前 } \\
\text { (平均值) }\end{array}$} & \multicolumn{2}{|c|}{ 洗 浄 後 } \\
\hline & & $20^{\circ} \mathrm{C}$ (平均値) & $40^{\circ} \mathrm{C}$ (平均值) \\
\hline \multirow{4}{*}{ エンドフレッシュA } & $3.33 \times 10^{-9}$ & $2.43 \times 10^{-13}$ & $2.29 \times 10^{-13}$ \\
\hline & $4.02 \times 10^{-9}$ & $2.25 \times 10^{-13}$ & $2.02 \times 10^{-14}$ \\
\hline & $5.51 \times 10^{-9}$ & $6.24 \times 10^{-13}$ & $7.33 \times 10^{-14}$ \\
\hline & $\left(4.29 \times 10^{-9}\right)$ & $\left(3.64 \times 10^{-13}\right)$ & $\left(7.21 \times 10^{-14}\right)$ \\
\hline \multirow{4}{*}{ アルベストBF } & $1.09 \times 10^{-8}$ & $4.05 \times 10^{-13}$ & $1.28 \times 10^{-13}$ \\
\hline & $3.87 \times 10^{-9}$ & $4.49 \times 10^{-13}$ & $1.16 \times 10^{-13}$ \\
\hline & $2.66 \times 10^{-9}$ & $1.02 \times 10^{-12}$ & $3.78 \times 10^{-14}$ \\
\hline & $\left(5.87 \times 10^{-9}\right)$ & $\left(6.52 \times 10^{-13}\right)$ & $\left(8.74 \times 10^{-14}\right)$ \\
\hline \multirow{4}{*}{ メディポールEX-1 } & $2.02 \times 10^{-9}$ & $2.02 \times 10^{-13}$ & $2.72 \times 10^{-13}$ \\
\hline & $2.86 \times 10^{-9}$ & $1.66 \times 10^{-13}$ & $6.30 \times 10^{-14}$ \\
\hline & $1.09 \times 10^{-10}$ & $1.68 \times 10^{-13}$ & $6.99 \times 10^{-14}$ \\
\hline & $\left(1.66 \times 10^{-9}\right)$ & $\left(1.79 \times 10^{-13}\right)$ & $\left(8.67 \times 10^{-1.4}\right)$ \\
\hline \multirow{4}{*}{ ステリザイム } & $6.63 \times 10^{-9}$ & $1.79 \times 10^{-13}$ & $1.02 \times 10^{-13}$ \\
\hline & $6.93 \times 10^{-9}$ & $2.88 \times 10^{-12}$ & $2.08 \times 10^{-14}$ \\
\hline & $6.06 \times 10^{-9}$ & $4.03 \times 10^{-13}$ & $1.18 \times 10^{-13}$ \\
\hline & $\left(6.54 \times 10^{-9}\right)$ & $\left(6.23 \times 10^{-13}\right)$ & $\left(8.09 \times 10^{-14}\right)$ \\
\hline \multirow{4}{*}{ 水道水（対照） } & $3.35 \times 10^{-9}$ & $1.71 \times 10^{-12}$ & $1.06 \times 10^{-12}$ \\
\hline & $2.25 \times 10^{-8}$ & $5.72 \times 10^{-13}$ & $2.03 \times 10^{-12}$ \\
\hline & $2.59 \times 10^{-9}$ & $1.02 \times 10^{-12}$ & $6.34 \times 10^{-13}$ \\
\hline & $\left(6.06 \times 10^{-9}\right)$ & $\left(9.48 \times 10^{-13}\right)$ & $\left(9.81 \times 10^{-13}\right)$ \\
\hline
\end{tabular}

\section{5. まと め}

(1) 製造直後の 4 種類の酵素洗剂原液を $4^{\circ} \mathrm{C}$ お よび $40^{\circ} \mathrm{C}$ に保存して $1.0 \%$ 液中のプロテアー ゼ活性を測定すると $4^{\circ} \mathrm{C}$ 保存では安定であ るが, $40^{\circ} \mathrm{C}$ 保存では 161 日目に活性が平均 38.0\%減少した。

(2) 反応温度 $40^{\circ} \mathrm{C}$ でのプロテアーゼ活性を 100

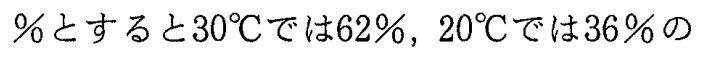
活性であった。

(3) 付着 ATP 濃度を指標として $20^{\circ} \mathrm{C}$ おるび 40 ${ }^{\circ} \mathrm{C}$ における酵素洗剂の洗浄力を比較すると
医器学 Vol. 70, No.12 (2000) ( 9 ) $40^{\circ} \mathrm{Cが} 10$ 倍優れていた。

(4) 酵素洗剂の能力を十分に引き出し, 効果的 な器械洗浄を行うためには製造後からの保 管を $4^{\circ} \mathrm{C}$ に保ち, 洗浄時には $40^{\circ} \mathrm{C} に て$ 行う ことが重要である.

\section{文献}

1) Rutara WA, Gergen MF, Jones JF, et al: Levels of microbial contamination on surgical instruments. Am J Infect Control, $26: 143-5,1998$.

2）伏見了, 野口悟司, 船越文男, 他: 生物学的 発光法による手術器械に付着した血液成分の分 析. 日本手術医学会誌, $20: 338-43,1999$.

3）野口悟司, 中谷 博, 池端信孝, 他: 手術器械 コンテナ自動回収洗浄システムにおける酵素洗 浄剤の有効性. 医器学, $65: 30-1,1995$.

4) Kunitz G: Crystalline soybean trypsin inhibitor. J Gen Physiol, 30:291-310,1947.

5) Lowry $\mathrm{OH}$, Rosebrough NJ, Farr AL, at al: Protein measurement with the Folin phenol reagent. J Biol Chem, 193 : 265-75, 1951.

6) Ishiura $S$, Murofushi $H$, Suzuki K, et al: Studies of a Calcium-activated Neutral protease from Chicken skeletal muscle. J Biochem, 84:225-30, 1978.

7) Beutler E, Baluda MC: Simplified determination of blood Adenosine Triphosphate using the Firefly system. Blood, $23: 688-$ 96, 1964.

8) Chappelle EW, Levin GV: Use of Firefly Bioluminescent reaction for rapid detection and counting of Bacteria. Biochem Med, 2: 41-52, 1968. 